\title{
Arsenic Content in Tissues of Fish from the River Elbe
}

\author{
O. ČELECHOVSKÁ ${ }^{1}$, Z. SVOBODOVÁ ${ }^{1,2}$, T. RANDÁK ${ }^{2}$ \\ ${ }^{1}$ University of Veterinary and Pharmaceutical Science, Brno, Czech Republic \\ ${ }^{2}$ University of South Bohemia, České Budějovice, \\ Research Institute of Fish Culture and Hydrobiology, Vodňany, Czech Republic
}

Received April 22, 2005

Accepted August 30, 2005

\begin{abstract}
Čelechovská O., Z. Svobodová, T. Randák: Arsenic Content in Tissues of Fish from the River Elbe. Acta Vet. Brno 2005, 74: 419-425.

The aim of the study was to evaluate arsenic content in tissues (muscle, liver, kidneys, gonads) of fish caught in selected localities along the River Elbe and its tributary the Vltava in 1999, 2002 and 2003, and in pools of the River Elbe in 2000. A total of 118 bream and 151 perch were examined by AAS. The highest muscle tissue arsenic concentrations were found in Zelčín in bream in $2003\left(0.17 \pm 0.08 \mathrm{mg} \cdot \mathrm{kg}^{-1}\right)$ and in perch in $2002\left(0.084 \pm 0.012 \mathrm{mg} \cdot \mathrm{kg}^{-1}\right)$. The highest arsenic concentrations in perch were found in the kidneys, followed by the liver, milt, muscle tissue and eggs. An increase $(P<0.01)$ in arsenic concentrations in 2003 (after floods) compared with 2002 was found in bream muscle tissues in Zelčín and in perch muscle tissues in Podolí; a decrease in arsenic concentrations was demonstrated in perch musculature in Verdek, Němčice, Hřensko $(P<0.01)$ and in bream musculature in Hřensko $(P<0.05)$. Arsenic contamination in the localities under study does not pose a major environmental or health risk.
\end{abstract}

River Vltava, Elbe pools, bream, perch, As distribution, AAS

Arsenic is brought to the environment through natural and anthropogenic routes. The most serious sources of arsenic pollution include emissions and waste water of the ore mining and processing industry, dye manufacture facilities, tanneries, and also thermal power plants, application of certain insecticides, herbicides, etc. Because arsenic accompanies phosphorus, it is also found in wash water. Arsenic has a considerable tendency to accumulate in bottom sediments (Pitter 1999). For that reason, issues relating to arsenic content in aquatic organisms, and sea fish in particular, have attracted considerable attention (Lai et al. 2001). A number of recent studies have dealt with arsenic compounds speciation in biological material (Khokiattiw ong et al. 2001; Pizarro et al. 2003; Šlejkovec et al. 2004), and particularly in aquatic organisms (Pergantis 2001; Kais e et al. 2001). The oxidation status of the arsenic atom is more important for the determination of toxicity than the compound's inorganic or organic nature. If, however, compounds with the same oxidation status are compared, then inorganic compounds are more toxic than the organic ones. The ratio between individual components changes with the fish species and the ambient - in running water the inorganic component is lower (up to $27 \%$ - EPA 2000).

The assessment of the arsenic contamination of the aquatic environment is based on results of fish tissue analysis. A number of studies assessing contamination levels in natural waters has been published (Foran et al. 2004; Bordajandi et al. 2003; Allen et al. 2001; Goldstein and DeWeese 1998). In the Czech Republic, arsenic contamination was investigated in the upper reaches of the River Tichá Orlice (S vobodová et al. 2004) and in North Moravian reservoirs ( studied (Svobodová et al. 2002a; Svobodová et al. 2002b; Foran et al. 2004). These authors reported higher arsenic concentrations in salmonids reared on fish farms compared

Address for correspondence:

Doc. Ing. Olga Čelechovská, $\mathrm{PhD}$

Department of Biochemistry, Chemistry and Biophysics

Faculty of Veterinary Hygiene and Ecology

University of Veterinary and Pharmaceutical Sciencies

Palackého 1-3,612 42 Brno Czech Republic

Phone +420 541562606

E-mail: celechovskao@vfu.cz

http://www.vfu.cz/acta-vet/actavet.htm 
with salmonids from natural water and gave increased arsenic concentrations in feed mixes based on sea-fish meal as the cause.

The study reported here focused on the main river in the Czech Republic, i.e. the Elbe, and its tributary, the Vltava. Tissues of fish caught there were analysed to determine arsenic contamination levels in selected localities, to map the arsenic distribution in fish tissues, and to assess the impact of the 2002 floods on the rivers' arsenic contamination levels.

\section{Materials and Methods}

This paper reports results of a study of arsenic concentrations in tissues of bream (Abramis brama L.) and perch (Perca fluviatilis L.) caught in various localities along the River Elbe (313th river km - Verdek, 256th $\mathrm{r}$. $\mathrm{km}-$ Němčice, 224th r. km - Valy, 160th r. km - Lysá, 116th r. km - Obříství, 21st r. km - Děčín and 2nd r. km - Hřensko) and in two locations in the lower reaches of the River Vltava (165th r. km - Podolí, 113th r. km - Zelčín).

In 1999 and 2003, fish from six locations were analyzed. In 2002, fish from seven locations along the Elbe were analyzed. In 2000, samples from four pools of the River Elbe were taken. In 1999, 2002 and 2003, samples from two localities along the River Vltava were also examined. Individual localities are shown in Fig. 1.

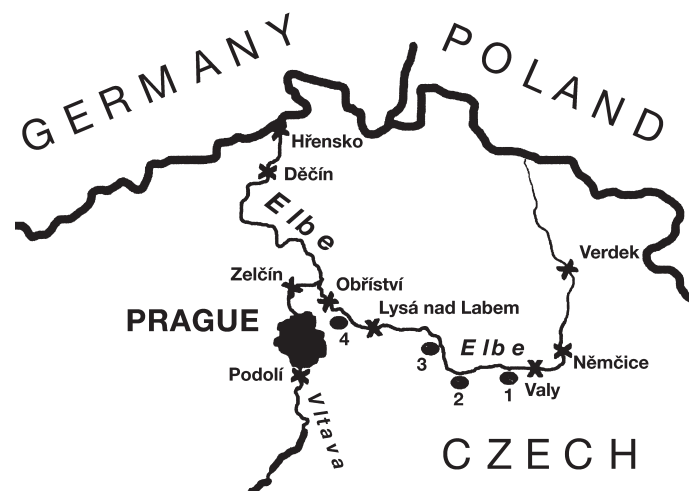

(1 - Lžovice pool, 2 - Polabec pool, 3 - Chvalovice pool, 4 - Libiš pool)

Fig. 1. Localities on the River Elbe monitored in 1999, 2000, 2002 and 2003

Samples in individual years were taken in late July. Standard methods in river fish studies were used both when catching the fish and taking samples. The fish were caught using an electric generator set located on a boat with an outboard. As soon as they were caught, the fish were weighed and their scales collected for age determination. Muscle samples were collected from fish caught in the Elbe and the Vltava, and muscle, liver, kidney and gonads samples were taken from fish caught in pools. The samples were put into plastic bags, labelled and transported in cooled containers to a freezer where they were stored at $-18^{\circ} \mathrm{C}$. The characteristics of the fish examined are given in Table 1 .

The samples were first mineralized by nitric acid and hydrogen peroxide in a microwave-heated laboratory autoclave (Uniclever, Plasmatronica, Poland) and then ashed with an addition of magnesium nitrate in a muffle oven at $450^{\circ} \mathrm{C}$. The ash was dissolved in hydrochloric acid, and $\mathrm{As}^{\mathrm{V}}$ was reduced to $\mathrm{As} \mathrm{s}^{\mathrm{III}}$. Arsenic was determined by the hydride technique on MHS-20 connected to the atomic absorption spectrometer Z-5000 (both from Perkin Elmer Comp). The detection limit $(3 \sigma)$ was $1 \mu \mathrm{g} \cdot \mathrm{kg}$, and the standard deviation of parallel determinations was less than 5\%. Standard reference material CRM No 278 (mussel tissue, BCR) and CRM No 185 (bovine liver, BCR) was used to verify the validity of the method. UNISTAT 5.1 software was used to statistically evaluate arsenic concentrations found.

\section{Results and Discussion}

First, a comparison was made of arsenic concentrations in muscle tissues between male and female fish caught in different localities in individual years. The levels found in both bream and in perch were comparable for both sexes. It was therefore possible to compare individual localities using values obtained from all of the fish examined, irrespective of their sex (Figs. 2, 3, 4.). 
This finding was verified by results from localities on the River Tichá Orlice (Svobodová et al. 2004) which showed no differences in muscle tissue arsenic concentrations between male and female brown trout. An important factor allowing comparison between arsenic concentrations in muscle tissue of fish from different localities

Table 1. The main characteristics of examined bream (Abramix brama L.) and perch (Perca fluviatilis L.)

\begin{tabular}{|c|c|c|c|c|c|c|c|c|c|}
\hline \multicolumn{5}{|c|}{ Bream (Abramis brama L.) } & \multicolumn{5}{|c|}{ Perch (Perca fluviatilis L.) } \\
\hline Locality & Sex & $\mathrm{n}$ & $\begin{array}{l}\text { Age (years) } \\
\text { Mean } \pm S D\end{array}$ & $\begin{array}{l}\text { Weight }(\mathrm{g}) \\
\text { Mean } \pm \mathrm{SD}\end{array}$ & Locality & Sex & $\mathrm{n}$ & $\begin{array}{l}\text { Age (years) } \\
\text { Mean } \pm S D\end{array}$ & $\begin{array}{l}\text { Weight }(\mathrm{g}) \\
\text { Mean } \pm \text { SD }\end{array}$ \\
\hline \multicolumn{5}{|l|}{1999} & \multicolumn{5}{|l|}{1999} \\
\hline Němčice & $\mathrm{M}$ & 5 & $2.2 \pm 0.5$ & $239 \pm 68$ & Němčice & $\mathrm{M}$ & 5 & 2.0 & $49 \pm 10$ \\
\hline \multirow{4}{*}{ Valy } & $\mathrm{F}$ & 1 & 2.0 & 200 & & $\mathrm{~F}$ & 3 & 2.0 & $55 \pm 15$ \\
\hline & juv & 3 & 2.0 & $120 \pm 5$ & Valy & $\mathrm{F}$ & 2 & 2.0 & $50 \pm 18$ \\
\hline & $\mathrm{F}$ & 1 & 6.0 & 1100 & Lysá n. L. & M & 5 & $16 \pm 0.9$ & $56 \pm 53$ \\
\hline & juv & 1 & 1.0 & 52 & & $\mathrm{~F}$ & 7 & $1.7 \pm 1.5$ & $108 \pm 183$ \\
\hline \multirow[t]{2}{*}{ Lysá n. L. } & M & 2 & 4.0 & 270 & Obříství & M & 4 & $2.5 \pm 1.0$ & $168 \pm 67$ \\
\hline & $\mathrm{F}$ & 3 & $3.3 \pm 1.5$ & $193 \pm 26$ & & $\mathrm{~F}$ & 1 & 3.0 & 205 \\
\hline \multirow[t]{2}{*}{ Obřiství } & M & 1 & 5.0 & 600 & Děčín & M & 3 & 2.0 & $107 \pm 18$ \\
\hline & $\mathrm{F}$ & 1 & 4.0 & 470 & & $\mathrm{~F}$ & 1 & 2.0 & 145 \\
\hline \multirow[t]{3}{*}{ Děčín } & M & 14 & $3.5 \pm 1.6$ & $391 \pm 276$ & Podolí & M & 3 & $1.7 \pm 1.1$ & $69 \pm 46$ \\
\hline & $\mathrm{F}$ & 5 & $4.6 \pm 1.5$ & $732 \pm 396$ & & $\mathrm{~F}$ & 11 & $1.5 \pm 0.7$ & $61 \pm 48$ \\
\hline & juv & 2 & 3.0 & $200 \pm 57$ & Zelčín & F & 7 & $1.6 \pm 0.5$ & $51 \pm 15$ \\
\hline \multirow{4}{*}{$\begin{array}{l}\text { Hřensko } \\
\text { Podolí } \\
\text { Zelčín }\end{array}$} & $\mathrm{F}$ & 3 & $7.0 \pm 1.0$ & $780 \pm 195$ & \multicolumn{5}{|l|}{2002} \\
\hline & M & 1 & 10 & 900 & \multicolumn{2}{|l|}{ Verdek } & 3 & $3.7 \pm 0.5$ & $67 \pm 14$ \\
\hline & M & 1 & 6.0 & 510 & \multirow{2}{*}{\multicolumn{2}{|c|}{$\begin{array}{l}\text { Němčice } \\
\text { Valy }\end{array}$}} & 7 & $4.0 \pm 0.9$ & $96 \pm 60$ \\
\hline & juv & 1 & 2.0 & 120 & & & 1 & 3.0 & 160 \\
\hline \multicolumn{5}{|l|}{2002} & \multicolumn{2}{|l|}{ Lysá n. L. } & 5 & $4.4 \pm 0.5$ & $220 \pm 133$ \\
\hline \multicolumn{2}{|l|}{ Lysá n. L. } & 6 & $6.0 \pm 0.6$ & $427 \pm 61$ & \multicolumn{2}{|l|}{ Obříství } & 5 & $4.6 \pm 1.4$ & $272 \pm 194$ \\
\hline \multicolumn{2}{|l|}{ Obříství } & 3 & $6.7 \pm 0.9$ & $547 \pm 86$ & \multicolumn{2}{|l|}{ Děčín } & 6 & $3.5 \pm 0.5$ & $103 \pm 23$ \\
\hline \multicolumn{2}{|l|}{ Děčín } & 5 & $5.4 \pm 0.8$ & $620 \pm 250$ & \multicolumn{2}{|l|}{ Hřensko } & 5 & $3.2 \pm 0.4$ & $119 \pm 14$ \\
\hline \multicolumn{2}{|l|}{ Hřensko } & 5 & $6.6 \pm 0.5$ & $745 \pm 94$ & \multicolumn{2}{|l|}{ Podolí } & 7 & $4.0 \pm 0.8$ & $67 \pm 16$ \\
\hline Zelčín & & 5 & $5.6 \pm 0.8$ & $449 \pm 66$ & \multicolumn{2}{|l|}{ Zelčín } & 8 & $4.3 \pm 1.0$ & $116 \pm 28$ \\
\hline 2003 & & & & & 2003 & & & & \\
\hline Němčice & & 3 & $5.7 \pm 0.6$ & $442 \pm 24$ & Verdek & & 7 & $3.9 \pm 0.7$ & $118 \pm 23$ \\
\hline Valy & & 1 & 6.0 & 1045 & Němčice & & 5 & $4.8 \pm 1.5$ & $183 \pm 131$ \\
\hline Lysán. L. & & 2 & $4.5 \pm 2.1$ & $368 \pm 223$ & Valy & & 4 & $4 \pm 0.8$ & $85 \pm 44$ \\
\hline Obříství & & 2 & $7.0 \pm 1.4$ & $725 \pm 198$ & Lysá n. L. & & 3 & $3.7 \pm 0.6$ & $90 \pm 31$ \\
\hline Děčín & & 5 & $4.4 \pm 1.1$ & $556 \pm 269$ & Děčín & & 2 & $4.5 \pm 0.7$ & $155 \pm 42$ \\
\hline Hřensko & & 3 & $6.0 \pm 1.7$ & $643 \pm 321$ & Hřensko & & 2 & $2.5 \pm 0.7$ & $115 \pm 64$ \\
\hline Podolí & & 5 & $6.6 \pm 0.5$ & $510 \pm 60$ & Podolí & & 5 & $3.4 \pm 0.6$ & $100 \pm 29$ \\
\hline Zelčín & & 5 & $4.6 \pm 0.5$ & $997 \pm 105$ & Zelčín & & 2 & $3.5 \pm 0.7$ & $58 \pm 11$ \\
\hline 2000 & & & & & 2000 & & & & \\
\hline Lžovice & $\mathrm{F}$ & 3 & 5.0 & $508 \pm 14$ & Lžovice & F & 6 & 2.0 & $85 \pm 31$ \\
\hline & M & 2 & 5.0 & $480 \pm 28$ & & M & 2 & 3.0 & $150 \pm 128$ \\
\hline Polabec & $\mathrm{F}$ & 2 & 4.0 & $154 \pm 65$ & Polabec & $\mathrm{F}$ & 4 & 3.0 & $72 \pm 29$ \\
\hline & M & 3 & 5.0 & $192 \pm 71$ & & M & 2 & & $67 \pm 18$ \\
\hline Chvalovice & $\mathrm{F}$ & 2 & 6.0 & $313 \pm 67$ & Chvalovice & $\mathrm{F}$ & 4 & 2.0 & $156 \pm 173$ \\
\hline & M & 3 & 4.0 & $367 \pm 195$ & & M & 3 & 3.0 & $112 \pm 38$ \\
\hline Libiš & $\mathrm{F}$ & 5 & 4.0 & $158 \pm 9$ & Libiš & M & 1 & 4.0 & 235 \\
\hline & M & 3 & 4.0 & $159 \pm 4$ & & & & & \\
\hline
\end{tabular}

$(\mathrm{n}=$ number of fish, $\mathrm{SD}=$ standard deviation $)$ 


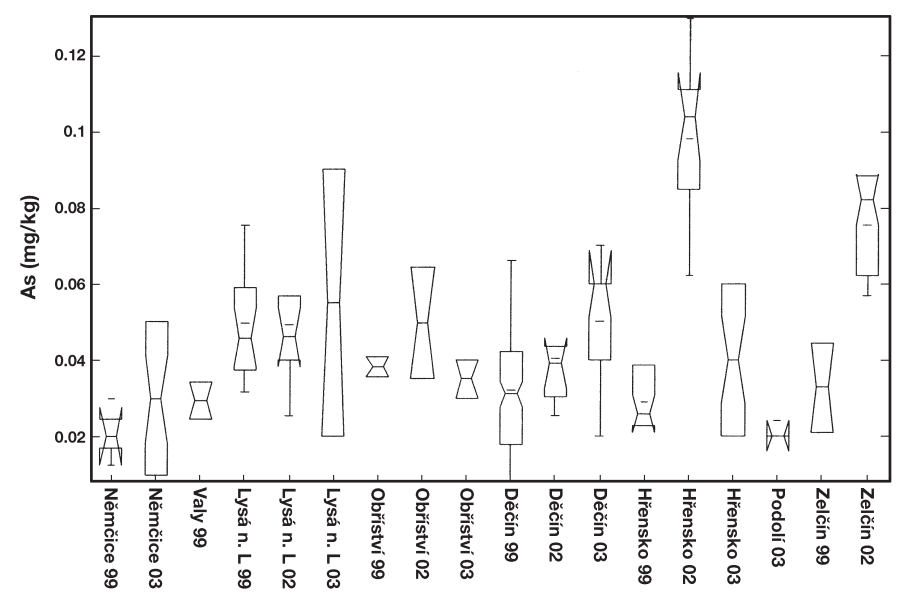

Lower $($ Upper $)$ Quartile = Bottom $($ Top) line of the box; Median = Middle line of the box; Lower $($ Upper $)$ Whisker $=$ Lower (Upper) adjacent value; Notch $=$ S.E.M.

Fig. 2. Arsenic concentrations in muscle tissue of bream (Abramis brama L.) from the localities monitored in 1999 , 2002 and 2003

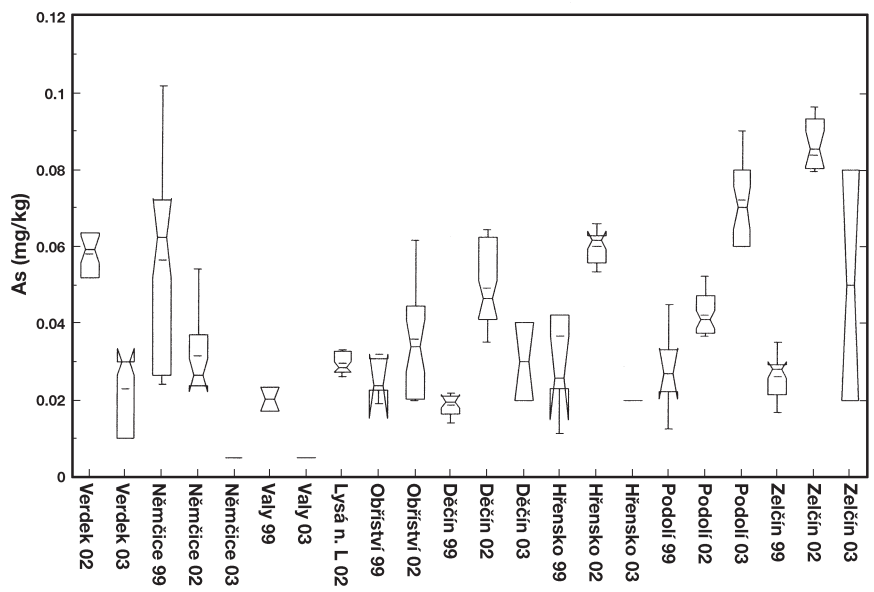

Lower $($ Upper) Quartile = Bottom (Top) line of the box; Median = Middle line of the box; Lower (Upper) Whisker $=$ Lower (Upper) adjacent value; Notch $=$ S.E.M.

Fig. 3. Arsenic concentrations in muscle tissue of perch (Perca fluviatilis L.) from the localities monitored in 1999 , 2002 and 2003

in individual years was the fact that no relation was found between arsenic concentrations in muscle tissue and weight or age of the fish. Linear relation tests were made whenever more than five bream or perch from one location were examined. B urg er et al. (2002) on the other hand found a positive correlation between body weight and arsenic contents in fish from the River Savannah. Another important factor that made comparison between arsenic concentrations in muscle tissue of bream and perch from different locations possible was the fact that all the fish in individual years were caught and sampled in late July, i.e. when water temperatures were practically the same. The influence of temperature on metabolic 


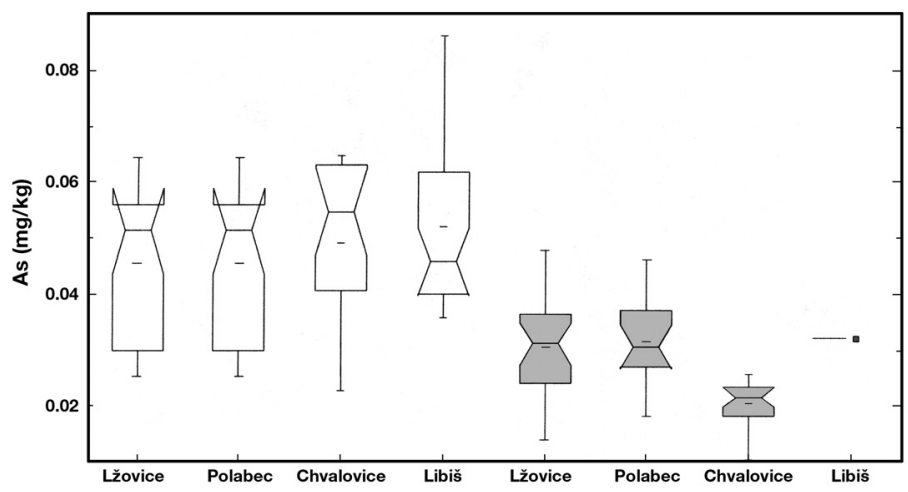

Lower $($ Upper $)$ Quartile $=$ Bottom $($ Top) line of the box; Median = Middle line of the box; Lower (Upper) Whisker $=$ Lower (Upper) adjacent value; Notch $=$ S.E.M.

Fig. 4. Arsenic concentrations in muscle tissue of bream ( $\square$ ) and perch ( 2000 .

transformation and elimination or accumulation of arsenic in fish tissues has been described by Chan and Huff (1977) and Svobodová et al. (2002b, 2004). These authors reported higher arsenic concentrations in fish tissues at lower water temperatures when detoxification processes slowed down.

Arsenic concentrations in bream muscle tissue in 1999 and 2002 (before the floods) and in 2003 (after the floods) are given in Fig. 2. The highest As concentrations were found in 2003 in Zelčín $\left(0.17 \pm 0.08 \mathrm{mg} \cdot \mathrm{kg}^{-1}\right.$ - not shown in Fig. 2.). The scatter analysis demonstrated higher fish tissue concentrations in that locality compared with those in Podolí $(P<0.01)$, Němčice, Obříství, Děčín and Hřensko $(P<0.05)$. Statistically significant changes in arsenic concentrations in fish muscle tissue in 2003 compared with pre-floods situation in 2002 were found only in Hřensko, where lower concentrations were found $(P<0.05)$ and in Zelčín, where higher concentrations were ascertained $(P<0.01)$.

Arsenic concentrations in perch muscle tissue in 1999, 2002 and 2003 are shown in Fig. 3. The highest concentrations were found in Podolí (2003) and Zelčín (2002). The scatter analysis demonstrated higher arsenic muscle tissue concentrations $(P<0.01)$ in Podolí (2003) compared with all other locations except for Zelčín. A statistically significant decrease in arsenic concentrations in muscle tissue of perch in 2003 compared with prefloods situation in $2002(P<0.01)$ was demonstrated in Verdek, Němčice and Hřensko, higher arsenic concentrations were found in Podolí $(P<0.01)$.

Arsenic concentrations in muscle tissue of bream and perch captured in pools of the Elbe in 2000 are shown in Fig. 4. No statistically significant differences in arsenic concentrations in bream muscle tissue between different localities were demonstrated. Arsenic muscle tissue concentrations in perch from Chvalovice were lower $(P<0.05)$ than in Lžovice and Polabec.

Although differences in muscle tissue arsenic concentrations in bream from pools in the Elbe were not statistically significant, arsenic concentrations in the liver, kidneys and gonads exhibited considerable variations (Fig. 5.). Arsenic concentrations in the kidneys and liver are higher in most cases than As concentrations in muscle tissue. This conclusion was also made by Suhendrayatna et al. (2001) in the case of Tilapia mossambica.

The bream from Chvalovice were an exception because their kidney, liver and gonads As concentrations were lower than their muscle tissue As concentrations. This finding is in 


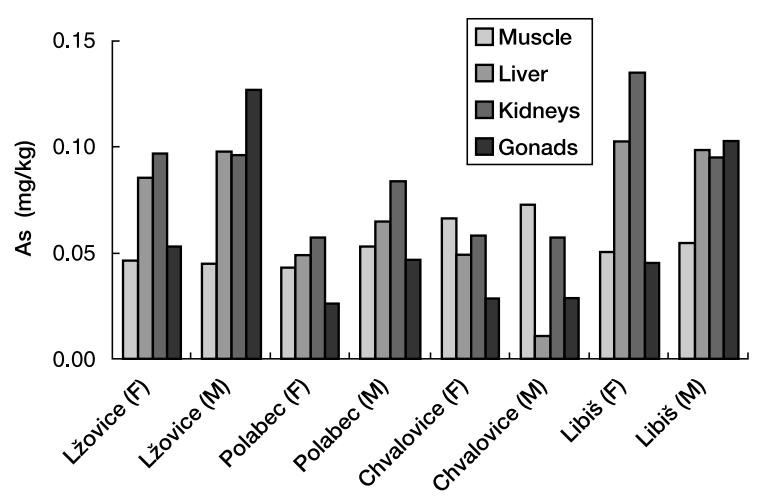

Fig. 5. Arsenic concentrations in tissue of female (F) and male (M) bream from pools of the Elbe (2000).

agreement with literary data (Chan and Huff 1997) indicating that methylation capacity changes with exposure, and that periods of high metabolism and As excretion alternate with periods when As is accumulating in tissues. Fig. 5 shows average As concentrations in male and female bream tissues in pools of the Elbe. While As concentrations in muscle tissues, liver and kidneys from one locality were similar for both male and female bream, As concentrations in eggs and milt differed $(P<0.05)$. Significant correlations were found only between As contents in the liver and eggs (correlation coefficient $r=0.8$ ), liver and milt $(\mathrm{r}=0.9)$, kidneys and milt $(\mathrm{r}=0.8)$ and kidneys and eggs $(\mathrm{r}=0.8)$.

\section{Obsah arsenu ve tkáních ryb z řeky Labe}

Cílem předkládané práce bylo zhodnotit obsah arsenu ve tkáních (svalovina, játra, ledviny, gonády) ryb odlovených z vybraných lokalit řeky Labe a jejího přítoku řeky Vltavy v letech 1999, 2002, 2003 a tůní Labe v roce 2000. Celkem bylo vyšetřeno 118 cejnů velkých a 151 okounů říčních metodou AAS. Nejvyšší koncentrace arsenu ve svalovině byly nalezeny v lokalitě Zelčín u cejna velkého v roce $2003\left(0,17 \pm 0,08 \mathrm{mg} \cdot \mathrm{kg}^{-1}\right)$ a u okouna říčního v roce $2002\left(0,084 \pm 0,012 \mathrm{mg} \cdot \mathrm{kg}^{-1}\right)$. Distribuce arsenu do tkání cejna velkého byla v pořadí od nejvyšší koncentrace: ledviny, játra, mlíčí, svalovina, jikry. Zvýšení $(P<0,01)$ koncentrace arsenu v roce 2003 (po povodni) oproti roku 2002 bylo zjištěno ve svalovině cejnů v lokalitě Zelčín a ve svalovině okounů v lokalitě Podolí; snížení koncentrace arsenu bylo prokázáno ve svalovině okounů v lokalitách Verdek, Němčice, Hřensko $(P<0,01)$ a ve svalovině cejnů v lokalitě Hřensko $(P<0,05)$. Kontaminace arsenem na sledovaných lokalitách nepředstavuje výrazné environmentální a zdravotní riziko.

\section{Acknowledgements}

This research was supported by Ministry of Education, Youth and Physical Training of the Czech Republic (Project MSM6215712402 and Project MSM 6007665809) and Project Labe III, IV (Ministry of Environment of the Czech Republic (VaV/650/5/03).

\section{References}

ADAMS MS, KAUSCH H, GAUMERT T, KRUGER KE 1996: The effect of the reunification of Germany on the water chemistry and ecology of selected rivers. Environ Conservation 23: 35-43

ALLEN GT, BLACKFORD SH, TABOR VM, CRINGAN MS 2001: Metals, boron and selenium in Neosho madtom habitats in the Neosho river in Kansas, U.S.A. Environ Monit Assess 66: 1-21

BORDAJANDI LR, GOMEZ G, FERNANDEZ MA, ABAD E, RIVERA J, GONZALEZ MJ 2003: Study on $\mathrm{PCBs}, \mathrm{PCDD} / \mathrm{Fs}$, organichlorine pesticides, heavy metals and arsenic content in frehwater fish species from the River Turia (Spain). Chemosphere 53: 163-171 
BURGER J, GAINES KF, BORING CS, STEPHENS WL, SNODGRASS J, DIXON C, MCMAHON M, SHUKLA S, SHUKLA T, GOCHFELD M 2002: Metal levels in fish from the Savannah river: Potential Hazards to fish and other receptors. Environ Res 89: 85-97

CHAN PC, HUFF J 1997: Arsenic carcinogenesis in animals and humans. Environ Carcin Ecotox Rews 15: 83-122

ENVIRONMENTAL PROTECTION AGENCY (EPA) 2000: Target analytes. http://www.epa.gov/ostwater/fishadvice/voll/ch4.pdf.

FORAN JA, HITES RA, CARPENTER DO, HAMILTON C, MATHEWS-AMOS A, SCHWAGER SJ 2004: A survey of metals in tissues of farmed Atlantic and wild Pacific salmon. Environ Tox Chem 23: 2108-2110

GOLDSTEIN RM, DEWEESE LR 1998: Comparison of trace element concentrations in tissue of common carp and implications for monitoring. J Amer Water Res Assoc 35: 1133-1140

KAISE T, KAMIDATE Y, YAMADA M, FURUSHO Y, HANAOKA K, FUJIWARA K 2001: A rapid arsenic speciation analysis by a reversed phase semimicro column and an inductively coupled plasma mass spectrometer. ICEBAMO, Schielleiten, Austria, L-23.

KHOKIATTIWONG S, GOESSLER W, PEDERSEN SN, COX R, FRANCESCONI KA 2001: Dimethylarsinoylacetate from microbial demethylation of arsenobetaine in seawater. Appl Organometal Chem 15: 481-489

LAI VWM, CULLEN WR, RAY S 2001:Arsenic speciation in sea scallop gonads. Appl Organometal Chem 15: 490-498

PERGANTIS SA 2001: Development and application of electrospray tandem mass spectrometry for arsenic speciation. ICEBAMO, Schielleiten, Austria, L-21.

PITTER P 1999: Hydrochemie. Vydavatelství VŠCHT Praha, 568 p.

PIZARRO I, GÓMEZ M, CÁMARA C, PALACIOS MA 2003: Arsenic speciation in environmental and biological samples. Anal Chim Acta 495: 85-98

ŘEHULKA J 2001: Chemical monitoring of three water-supply reservoirs, using fish as bioindicators. Czech J Anim Sci 46: 217-230

SVOBODOVÁ Z, ŽLÁBEK V, ČELECHOVSKÁ O, RANDÁK T, MÁCHOVÁ J, KOLÁŘOVÁ J, JANOUŠKOVÁ D 2002a: Content of metals in tissues of marketable common carp and in bottom sediments of selected ponds of South and West Bohemia. Czech J Anim Sci 47: 339-350

SVOBODOVÁ Z, ČELECHOVSKÁ O, MÁCHOVÁ J, RANDÁK T 2002b: Content of arsenic in market-ready rainbow trout (Oncorhychus mykiss). Acta Vet Brno 71: 361-367

SVOBODOVÁ Z, ČELECHOVSKÁ O, KOLÁŘOVÁ J, RANDÁK T, ŽLÁBEK V 2004: Assessment of metal contamination in the upper reaches of the Tichá Orlice river. Czech J Anim Sci 49: 458-464

SUHENDRAYATNA OHKI A, NAKAJIMA T, MAEDA S 2001: Metabolism and organ distribution of arsenic in the freshwater fish Tilapia mossambica. Appl Organometal Chem 15: 566-571

ŠLEJKOVEC Z, BAJC Z, DOGANOC DZ 2004: Arsenic speciation patterns in freshwater fish. Talanta 62: 931-936 